\title{
Penerapan Media Gambar dan Kartu Huruf Untuk Meningkatkan Keterampilan Membaca Permulaan
}

\author{
Ida Bagus Made Eka Yoni Adnyana Putra \\ Jurusan Pendidikan Guru Sekolah Dasar, Fakultas IImu Pendidikan \\ Universitas Pendidikan Ganesha \\ Singaraja, Indonesia \\ E-mail: putra_ekayoni@yahoo.com
}

\begin{abstract}
Abstrak
Penelitian ini bertujuan (1) meningkatkan keterampilan membaca permulaan siswa, (2) menemukan langkah-langkah pembelajaran yang tepat didasarkan pada penerapan media gambar dan kartu huruf sebagai media pembelajaran, dan (3) mengetahui respon siswa terhadap penerapan media gambar dan kartu huruf sebagai media pembelajaran. Penelitian ini dibuat dalam bentuk penelitian tindakan dengan menggunakan dua siklus. Setiap siklus terdiri dari 2 kali pertemuan. Subjek penelitian ini adalah siswa kelas I semester II di SD Negeri 4 Takmung-Klungkung tahun ajaran 2010/2011(sebanyak 23 orang). Pengumpulan data dilakukan dengan metode observasi dan tes tindakan.Data yang diperoleh dianalisis secara deskriptif kualitatif.Hasil penelitian ini menunjukkan bahwa penggunaan media gambar dan kartu huruf sebagai media pembelajaran dapat meningkatkan keterampilan membaca permulaan siswa. Pada siklus I ketuntasan belajar siswa hanya mencapai $73,91 \%$, hal ini menunjukan keterampilan membaca siswa masih tergolong cukup karena $27 \%$ dari jumlah siswa belum mencapai ketuntasan belajar dengan nilai yang ditentukan. Pada siklus II terjadi peningkatan ketuntasan belajar, yakni dari 23 siswa, 19 siswa atau 82,60\%dari jumlah siswa telah mencapai ketuntasan belajar, sehingga target yang ditentukan tercapai.
\end{abstract}

Kata kunci: media gambar, kartu huruf, dan keterampilan membaca permulaan.

\section{Pendahuluan}

Keterampilan berbahasa lisan maupun tulis memegang peranan penting dalam kehidupan manusia.Keterampilan berbahasa meliputi mendengarkan, berbicara, membaca, dan menulis.Keempat komponen ini merupakan satu kesatuan. Apabila salah satu komponen tidak dapat terpenuhi, maka akan mengganggu keterampilan berbahasa seseorang. Bahasa seseorang mencerminkan pikirannya.Semakin terampil seseorang berbahasa, semakin cerah dan jelas pikirannya (Tarigan, 1990). Bahasa tidak hanya digunakan dalam kegiatan berbicara, namun juga digunakan dalam kegiatan mendengarkan, menulis dan membaca. Salah satu dari kegiatan tersebut, yaitu kegiatan membaca memiliki peran penting untuk menyerap informasi-informasi ataupun ilmu pengetahuan yang disampaikan lewat bahasa tulis. Selain itu, dengan membaca,wawasan dan pengetahuan seseorang akan semakin bertambah, sehingga keterampilan membaca penting untuk dikusai setiap orang.

Kemampuan membaca seseorang berkembang sejak ia mulai memasuki jenjang pendidikan formal. Pada jenjang pendidikan awal atau tingkat SD telah diajarkanketerampilan berbahasa, khususnya keterampilan membaca.Pembelajaran bahasa khususnya membaca di sekolah dasar bertujuan untuk memperkenalkan kaidahkaidah membaca yang benar pada siswa.Kaidah-kaidah tersebut mencakup pelafalan abjad yang berpedoman pada EYD, dan pelafalan kata yang tidak dipengaruhi oleh lafal daerah (dialek).Pada taraf ini guru memiliki peran yang penting untuk dapat mengembangkan kemampuan membaca siswa. Seorang guru harus mampu 
mengajarkan dan melatih keterampilan siswa agar mampu menguasai bahasa yang baik dan benar. Keterampilan berbahasa yang baik dan benar akan membantu siswa dalam memperoleh informasi yang dibutuhkannya.

Pada dasarnya proses
pembelajaran berbahasa pada anak harus menyesuaikan dengan tahap umur anak karena pembelajaran berbahasa anak SD kelas rendah berbeda dengan anak SD kelas tinggi. Anak SD kelas rendah belum memiliki kemampuan membaca yang baik dan benar, sehingga guru harus mampu meningkatkan kreativitas dan motivasi siswa agar belajar. Oleh sebab itu, guru memerlukan media sebagai sarana pembelajaran. Penggunaan media sangat penting dalam proses belajar-mengajar terutama untuk tingkat SD. Piaget (dalam Sudono, 2000) menyatakan bahwa usia 711 tahun disebut tahap operasional konkret karena anak memahami pengertian atau konsep-konsepnya lewat benda konkret. Pada masa ini siswa masih berpikir konkret dan belum mampu berpikir abstrak.Kehadiran media sangat membantu siswa dalam memahami konsep (Djamarah dan Aswan Zain, 2002). Hal senada juga diungkapkan oleh Titi Sayono (dalam Purwanto dan Djenah Alim, 1997) bahwa siswa SD umumnya ada dalam taraf berpikir konkret.Materi dan konsep yang diajarkan pada anak harus diawali dengan hal-hal yang konkret. Namun, sampai saat ini guru belum memanfaatkan alat atau media pembelajaran secara maksimal dalam pelaksanaan proses belajar mengajar.

Menurut Lerner dalam Mulyono Abdurrahman (2000) kemampuan membaca merupakan dasar untuk menguasai berbagai bidang studi. Berdasarkan kenyataan tersebut, perlu adanya suatu upaya yang diduga mempunyai pengaruh kepada perbaikan kesiapan membaca anak Kelompok Bermain dan termasuk di Kelompok Bermain pada TK Labor FKIP Universitas Riau.

Membaca merupakan sebuah aktivitas dari berbagai organ tubuh. Menurut Tampubolon (1996) membaca merupakan aktivitas fisik dan mental. Sementara itu Barbara D. Day (1994) mendefinisikan secara luas hinggga pada pengamatan tanda dari teks lingkungan sosial. Horocks dan Schoonover (Rita Kurnia 2010) menyatakan bahwa kesiapan membaca individu melibatkan dirinya dan pengalaman belajar di sekolah, dan faktor dari kesiapan membaca yaitu kesiapan fisik, kesiapan psikologis, kesiapan pendidikan dan kesiapan IQ. Keempat faktor itu saling mendukung satu dengan yang lainnya (Fahim Mustafa, 2005). Menurut Harris dan Mercer dalam Mulyono Abrurrahman (2000) lima tahapan kemampuan membaca, yaitu kesiapan membaca, membaca permulaan, keterampilan membaca cepat, membaca luas, dan membaca yang sesungguhnya. Kesiapan anak untuk membaca dilihat dari keinginan yang senang untuk membukabuka buku, memegang buku, dan berpurapura menulis/mencoret-coret.

Bersumber pada Depdiknas (2007) tentang aspek bahasa dalam hal membaca anak yaitu: 1) membedakan kembali suara/bunyi tertentu; 2) membedakan kata-kata yang mempunyai suku kata awal/akhir yang sama; 3) menirukan kembali bunyi/suara tertentu; 4) menirukan kembali 4-5 urutan kata. Selanjutnya menurut Kurikulum 2004 yakni tentang kemampuan mengenal huruf berdasarkan kompetensi dasar indikator yang dicapai: 1) anak dapat mengenal huruf a-z; 2) anak dapat menunjukkan huruf sederhana dengan simbol dan lambangnya; 3) anak dapat menyebutkan berbagai bunyi/suara tertentu pada huruf a-z; 4) anak dapat meniru gambar huruf a$z$.

Kartu huruf di sini dipahami sebagai media (alat) dalam pengajaran, yang mana melaluinya simulasi dari inti pengajaran disampaikan baik secara deskriptif maupun demonstratif, yang tentunya ini menandaskan pada fungsinya sebagai penyampai pesan (Gagne dalam Rita, 2009). Dalam konteks media pembelajaran bagi AUD, media merupakan segala alat fisik yang dapat menyajikan pesan serta merangsang anak didik untuk belajar (Briggs dalam Rita, 2009). Melihat wujud dan cara penggunaannya, media terdiri atas: 1) media grafis; 2) media audio; dan 3) media proyeksi diam (Sadiman, 2006). 
Media yang sifatnya gambar dapat juga disebut sebagai media grafis atau lebih dikenal juga bentuk media visual. Maka kartu huruf bergambar di sini merupakan media bergambar tentang sesuatu (baik benda, lanskap atau suasana tertentu) lalu disertakan dengan huruf yang mengarah pada pembacaan dari gambar yang ada di kartu tersebut.

Kenyataannya,sampai saat ini pemanfaatan media dalam pembelajaran belum dilakukan secara maksimal oleh guru. Hal tersebut berdampak pada keterampilan membaca siswa SD secara umum masih rendah. Hal ini sesuai dengan hasil penelitian-penelitian mahasiswa diantaranya: Made Oktha Artika (2003), Niti Suartiari (2007), dan Ardana Bukian (2004). Hasil penelitian tersebut menunjukkan bahwa kualitas keterampilan membaca siswa masih kurang. Hal yang sama juga terjadi pada siswa Sekolah Dasar Negeri 4 TakmungKlungkung. Keterampilan membaca siswa kelas I masih rendah. Hal ini disebabkan oleh kesulitan-kesulitan yang dialami siswa dalam pengucapan lafal yang kurang jelas, siswa masih takut salah bahkan ada yang memilih diam. Berdasarkan kenyataan itulah, perlu dilaksanakan penelitian untuk meningkatkan ketrampilan mebaca permulaan siswa kelas I SD Negri 4 Takmung. Pertimbangan pemilihan lokasi penelitian ini adalah bahwa sekolah dasar tersebut (1) cukup dikenal masyarakat lingkungannya, (2) belum pernah dijadikan tempat penelitian. Dipinnya kelas I sebagai subjek penelitian karena siswa kelas I sekolah dasar masih dalam tarap berpikir kongkrit.

Berdasarkan observasi dan wawancara dengan wali kelas I Sekolah Dasar Negri 4 Takmung, Ida Ayu Pt Candra Wati menyatakan bahwa kriteria ketuntasan minimal yang ditetapkan di Sekolah Dasar Negeri 4 Takmung sebesar 70 . Nilai rata-rata keterampilan membaca siswa hanya mencapai 65 .

Secara keseluruhan pencapaian nilai rata-rata masih tergolong kurang dari yang ditetapkan sekolah. Jika dilihat dari pencapaian nilai tiap individualnya, ada 8 siswa yang sudah mencapai KKM dengan nilai 70 ke atas, sedangkan 15 siswa yang mendapat nilai di bawah KKM yang ditetapkan sekolah tersebut perlu mendapat tindakan lebih lanjut. Keterampilan membaca permulaan siswa yang hanya mencapai nilai rata-rata 65 disebabkan oleh beberapa faktor sebagai berikut. (1) Pengucapan lafal masih ada siswa yang belum sesuai, misalnya pengucapan huruf $R$ yang sering diucapkan L, sehingga kalimat yang diucapkan memiliki makna berbeda; (2) Siswa takut salah dan kurang percaya diri ketika berada di depan kelas sehingga dalam membaca menjadi agak terbatabata; (3) Aspek-aspek yang lain pun perlu mendapat perhatian, seperti kemampuan menyusun kata-kata, membaca tanda baca (titik, koma, tanda tanya), dan kelancaran dalam membaca. Semua hal ini memiliki hubungan yang sangat erat dalam keterampilan membaca, apabila salah satu mengalami hambatan maka keterampilan membaca pun dapat terganggu. Hal ini juga didukung oleh hasil wawancara pada hari senin, tanggal 9 Januari 2011 dengan wali kelas dan juga siswa. Salah satu penyebab rendahnya keterampilan membaca dalam mata pelajaran Bahasa Indonesia adalah cara belajar yang hanya bersumber pada buku pelajaran yang dipakai disekolah. Oleh sebab itu, pembelajaran keterampilan membaca kurang diminati oleh siswa.

Berdasarkan hal tersebutlah dilakukan penelitian dengan menggunakan mediagambar dan kartu huruf untuk meningkatkan keterampilan membaca permulaan siswa. Upaya tersebut diharapkan menjadi salah satu solusi untuk meningkatkan keterampilan membaca anak sehingga KKM di Sekolah Dasar Negeri 4 Takmung dapat ditingkatkan.

\section{Metode}

Subjek sasaran penelitian ini adalah siswa kelas I semester II SD Negeri 4 Takmung tahun ajaran 2010/2011 sebanyak 23 siswa yang terdiri dari 14 laki-laki dan 9 perempuan, dan yang perlu mendapat tindakan yakni sebanyak 15 orang siswa. Hal ini dikarenakan secara umum keterampilan membaca permulaan di SD Negeri 4 Takmung masih rendah dengan nilai rata- 
rata keterampilan membaca permulaan siswa dibawah kriteria ketuntasan minimal. Di SD Negeri 4 Takmung, nilai rata-rata ketuntasan minimal yang ditetapkan sekolah yakni sebesar 70 , sedangkan nilai rata-rata keterampilan membaca permulaan siswa hanya mencapai 65.Mc. Niff (1992) menyebutkan bahwa penelitian tindakan kelas merupakan suatu bentuk penelitian refleksi diri kolektif yang dilakukan partisipannya (guru, siswa, peneliti, pimpinan sekolah, pengawas) dalam situasi sosial untuk meningkatkan penalaran praktek pendidikan dan praktek sosialnya. Menurut Kemmis, 1993 (dalam Raka Joni 1998) penelitian tindakan kelas merupakan sebuah inkuiri yang bersifat refleksi diri yang dilakukan oleh partisipan dalam situasi sosial termasuk kependidikan dengan maksud untuk meningkatkan kemantapan rasionalitas berdasarkan (a) praktek-praktek sosial maupun kependidikan, (b) pemahaman terhadap praktek-praktek tersebut, dan (c) situasi pelaksanaan praktek-praktek pembelajaran.

Berdasarkan pengertian di atas, dapat disimpulkan bahwa PTK merupakan penelitian yang dilakukan dalam sebuah kelas, yang mencangkup model pembelajaran serta faktor-faktor lainnya yang dapat mempengaruhi hasil belajar siswa. Penelitian ini menggunakan jenis penelitian tindakan kolaboratif, yaitu kolaborasi atau kerjasama antara guru dan peneliti.Peneliti dan guru menyiapkan instrumen obsevasi/evaluasi, ikut terlibat dalam pembelajaran, serta melaksanakannya sesuai dengan skenario yang ada.Penelitian tindakan kelas ini dilakukan pada semester II yang bersifat reflektif dengan melakukan tindakantindakan tertentu agar dapat memperbaiki atau meningkatkan praktik-praktik pembelajaran di kelas secara profesional.Penelitian ini dilaksanakan dalam dua siklus. Setiap siklus menggunakan model pendekatan yang dikemukakan oleh Kemmis dan McTaggaarat (1997) yang dalam pelaksanaanya terdiri dari empat tahap, yaitu: (1) rencana tindakan, (2) pelaksanaan tindakan, (3) observasi dan evaluasi tindakan, dan (4) refleksi.
Rencana Tindakan, Dalam perencanaan ini disusun rencana tidakan yang akan dilakukan, adapun langkahlangkah yang ditempuh adalah sebagai berikut: 1) Peneliti bersama guru meyiapkan silabus Bahasa Indonesia; 2) Peneliti dibantu guru membuat RPP sesuai materi ajar Bahasa Indonesia; 3) Menyiapkan instrument berupa lembar observasi (ceklis); 4) Meyiapkan tes hasil belajar; 5) Melakukan evaluasi hasil belajar.Pelaksanaan Tindakan, Dalam tahap tindakan ini kegiatan yang dilaksanakan oleh peneliti dan guru antara lain sebagai berikut. 1) Peneliti bersama guru melaksanakan persiapan mengajar; 2) Peneliti melaksanakan pembelajaran sesuai RPP dan mengenalkan materi pembelajaran dengan menggunakan media gambar dan kartu huruf; 3) Untuk mengetahui tingkat kemajuan keterampilan membaca permulaan, peneliti bersama guru mengamati setiap penampilan dari masing-masing siswa; 4) Peneliti mencatat hasil pengamatan pada lembar observasi.Observasi dan Evaluasi, Observasi merupakan pengamatan terhadap pelaksanaan tindakan yang berlangsung di kelas.Observasi dilakukan untuk memperoleh data yang lengkap dan akurat terhadap pelaksanaan tindakan. Pengamatan dilakukan oleh guru kelas di sekolah tersebut dengan cara mencatat semua kegiatan selama tindakan berlangsung di kelas. Semua kegiatan itu dicatat dalam instrumen observasi yang telah disediakan. Berdasarkan observasi yang telah dilakukan tersebut, adapun data yang diperoleh, yakni:1) penerapan permainan kartu huruf sebagai media pembelajaran dapat meningkatkan keterampilan membaca permulaan; 2) penerapan media gambar sebagai media pembelajaran dapat merangsang minat belajar siswa, dan 3) penerapan media gambar dan kartu huruf memberikan motivasi pada guru dalam proses pembelajaran, sehingga mempengaruhi peningkatan hasil belajar siswa. Evaluasi terhadap

hasil dilaksanakan setelah tindakan secara tuntas dilakukan.Evaluasi dilaksanakan untuk mengetahui hasil belajar siswa.Evaluasi yang dilaksanakan 
berpedoman pada kriteria keterampilan membaca.Berikut diuraikan kriteria penilaian dan penskoran yang sudah disiapkan untuk menentukan tingkat keterampilan membaca permulaan siswa.Selain itu, hasil tes juga dianalisis berdasarkan kriteria ketuntasan dengan berpedoman pada sistem penilaian di sekolah SD Negeri 4 TakmungKlungkung.Siswa dikatakan tuntas secara klasikal apabila $75 \%$ dari jumlah siswa yang ada di sekolah itu memperoleh nilai 70 ke atas.Refleksi, Berdasarkan hasil analisis data pada pelaksanaan tindakantindakan siklus I, maka penafsiran dengan cermat dapat dilakukan. Jika hasil refleksi menunjukan masih terdapat kekurangan, maka perlu dibuatkan perencanaan yang lebih baik untuk melaksanakan tindakan siklus II, sehingga peneliti memperoleh gambaran mengenai kekurangan dan kelebihan yang telah dilaksanakan pada siklus I.Secara umum, setiap siklus dilaksanakan melalui 4 tahapan seperti yang dijelaskan di depan, tetapi tahapan yang berbeda dari masing masing siklus lebih dominan pada tahapan pelaksanaan dan tahap refleksi/revisi. Dengan demikan, siklus berikutnya sangat dipengaruhi oleh hasil analisis data siklus sebelumnya dan refleksi yang diajukan untuk merevisi pelaksanaan siklus berikutnya.

Data dalam penelitian ini adalah data tentang kemampuan siswa membaca permulaan secara kuantitatif sebagai data utama dan perilaku guru serta siswa dalam proses belajar mengajar sebagai data pelengkapnya. Data yang dianalisis dengan cara deskkriptif kualitatif adalah data yang didapat dari hasil observasi dan wawancara, yaitu mengenai prilaku guru dan siswa, kesan siswa dalam PBM sebagai data pendukungnya, dan akan diuraikan satu persatu sebagai berikut: a) Metode Observasi, Observasi adalah kegiatan memperhatikan sesuatu objek dengan menggunakan seluruh alat indra (Arikunto. 1998). Observasi juga didefinisikan sebagai suatu cara untuk mengadakan penilaian dengan jalan mengadakan pengamatan secara langsung dan sistematis (Nurkencana, dkk. 1990). Berdasarkan pengertian tersebut, dari berbagai jenis observasi yang dapat digunakan, peneliti menggunakan jenis observasi ditinjau dari situasi yang diobservasi, yakni observasi terhadap situasi yang dimanipulasi.

Pada kegiatan observasi ini, situasi kegiatan telah dirancang oleh pengobservasi. Kegiatan tersebut dirancang, yakni berupa RPP yang telah dibuat sebelumnya dan dilaksanakan pada siklus I dan II. Peneliti juga menggunakan obervasi langsung. Pengamatan dilaksanakan saat proses belajar mengajar berlangsung di kelas. Guru hanya sebagai pengamat atau tidak terlibat aktif dalam proses belajar mengajar. Format observasi yang digunakan berupa cek-list. Pada saat pengamatan, format obervasi yang digunakan terdiri atas format obervasi untuk peneliti dan format obervasi untuk siswa.

Pada masing-masing format observasi tersebut berisi aspek-aspek yang diamati pada saat pembelajaran berlangsung. b) Metode Tes, Tes merupakan serangkaian pertanyaan atau latihan atau alat lain yang digunakan untuk mengukur keterampilan, intelegensi, kemampuan atau bakat yang di miliki oleh individu atau kelompok (Arikunto. 1998). Tes juga didefinisikan sebagai suatu cara untuk mengadakan penilaian yang berbentuk suatu tugas atau serangkaian tugas yang harus dikerjakan oleh anak atau sekelompok anak menghasilkan suatu nilai tentang tingkah laku atau prestasi anak tersebut, yang dapat dibandingkan dengan nilai yang dicapai anak-anak yang lain atau dengan nilai standar yang ditetapkan (Nurkencana, dkk. 1990).

Tes hasil belajar dapat dibedakan menjadi beberapa jenis ditinjau dari beberapa sudut pandang. Pada penelitian ini, jenis tes yang digunakan adalah tes berdasarkan bentuk respon yakni berupa tes tindakan. Tes tindakan, yakni apabila jawaban atau respon yang diberikan oleh anak itu berbentuk tingkah laku. Metode tes ini digunakan yaknidengan menyuruh siswa membaca dengan media gambar dan kartu huruf yang diberikan oleh guru.Data yang berupa kemampuan siswa dalam membaca permulaan akan dianalisis secara deskriptif kualitatif dengan cara penskoran kemudian 
dijumlahkan dan dibuat tabel. Penelitian ini dikatakan berhasil jika siswa mencapai KKM ketuntasan dalam belajar keterampilan penggunaan kartu huruf dalam pembelajaran Bahasa Indonesia minimal $75 \%$ ke atas. Rata-rata kelas mendapat nilai 70 ke atas.

\section{Hasil dan Pembahasan}

Siklus I, Pelaksanaan rencana tindakan pada penelitian ini telah disesuaikan dengan tahap-tahap dan prosedur yang telah ditentukan sebelumnya. Berdasarkan pelaksanaan tersebut, data yang diperoleh berupa data hasil observasi yang telah dilakukan terhadap guru dan siswa selama pelaksanaan penelitian tindakan kelas. Dari hasil observasi tersebut didapat data sebagai berikut, yakni: (1) penerapan permainan kartu huruf sebagai media pembelajaran dapat meningkatkan keterampilan membaca permulaan, (2) penerapan media gambar sebagai media pembelajaran dapat merangsang minat belajar siswa, dan (3) penerapan media gambar dan kartu huruf memberikan motivasi pada guru dalam proses pembelajaran sehingga mempengaruhi peningkatan hasil belajar siswa.Seperti yang dikemukakan di depan, pada refleksi awal ditemukan masalah di dalam pembelajaran membaca permulaan.

Kendala itu telah ditindaklanjuti dengan perencanaan dan pelaksanaan tindakan di kelas sehingga didapatkan suatu hasil tindakan. Pelaksanaan tindakan siklus I di kelas adalah penerapan model pembelajaran dengan media gambar sebagai model pembelajaran untuk meningkatkan keterampilan membaca, dalam hal ini siswa membaca denganmenggunakan media gambar dan kartu huruf yang telah diamatinya. Langkah- langkah pelaksanaannya sesuai dengan sekenario tindakan yang telah dipaparkan dalam subbab III bagian pelaksanaan tindakan.

Berdasarkan penelitian pada siklus I yang dilaksanakan pada tanggal 09 Januari 2011 diperoleh data sebagai berikut.

Kegiatan pembelajaran dibagi menjadi tiga tahap yaitu, pendahuluan, kegiatan inti, dan penutup yang akan diuraikan secara terperinci.a) Kegiatan Pendahuluan, Pada kegiatan pendahuluan kurang lebih 10 menit, dilaksanakan koordinasi kelas. Kemudian, dilanjutkan dengan apersepsi untuk menggali pengetahuan siswa yang telah dimiliki siswa sebelumnya, setelah itu barulah disampaikan tujuan pembelajaran; b) Kegiatan Inti, Pada kegiatan inti dibagi menjadi tiga tahapan yaitu: 1) Kegiatan eksplorasi, ada beberapa kegiatan pada tahap ini.

Pertama, siswa diberikan arahan tentang cara penggunaan kartu huruf dan penggunaan media gambar. Siswa sangat antusias menyimak penjelasan tentang cara membaca dengan menggunakan media gambar. Selanjutnya barulah diberikan konsep bagaimana cara membaca dengan menggunakan kartu huruf yang disertai dengan contoh. Kemudian,kegiatan dilanjutkan dengan mengarahkan siswa untuk mengambil gambar dan kartu huruf kemudian disusun menjadi kata untuk dibaca.Kegiatan elaborasi, pada kegiatan elaborasi yang sepenuhnya berperan adalah siswa, sedangkan peranan peneliti hanya sebagai fasilitator.

Setelah mendapat arahan dari peneliti dan guru siswa dengan cepat mengambil gambar yang sudah disediakan di depan kelas. Begitu siswa mendapatkan gambar dan kartu huruf, kemudian keduanya media tersebut digunakan untuk membaca. Setelah itu, setiap siswa berlatih menggunakan kartu huruf dengan teman sebangkunya sebelum siswa membaca di depan kelas. Siswa dapat belajar membaca dengan menggunakan media gambar dan kartu huruf, kemudian peneliti memanggil siswa satu persatu ke depan kelas; c) Kegiatan Penutup, Pada kegiatan penutup kurang lebih 10 menit sebelum pembelajaran diakhiri, peneliti bersama siswa menyimpulkan materi yang telah dipelajari yaitu membaca dengan menggunakan media gambar dan kartu huruf.

Selanjutnya, peneliti menugaskan siswa agar mereka belajar membaca di rumah dengan menggunakan media yang ada di sekitar lingkungannya. Peneliti mengakhiri dengan salam penutup. Bel istirahat pun berbunyi siswa pun istirahat. 
Hasil evaluasi membaca

permulaan pada siklus I ini dapat dilihat pada tabel di bawah ini.

Tabel 1: Hasil Evaluasi Membaca Permulaan Siswa Kelas 1 SD Negeri 4 TakmungKlungkung pada Siklus I

\begin{tabular}{|c|c|c|c|c|c|c|c|}
\hline \multirow{2}{*}{ No. } & \multirow{2}{*}{ Kode Siswa } & \multicolumn{4}{|c|}{ Aspek yang dinilai } & \multirow{2}{*}{ Jumlah } & \multirow{2}{*}{$\begin{array}{l}\text { Rata- } \\
\text { rata }\end{array}$} \\
\hline & & 1 & 2 & 3 & 4 & & \\
\hline 1 & 001 & 68 & 67 & 75 & 70 & 280 & 70 \\
\hline 2 & 002 & 61 & 60 & 70 & 62 & 252 & 63 \\
\hline 3 & 003 & 68 & 70 & 75 & 71 & 284 & 71 \\
\hline 4 & 004 & 65 & 71 & 75 & 69 & 280 & 70 \\
\hline 5 & 005 & 75 & 77 & 73 & 75 & 300 & 75 \\
\hline 6 & 006 & 75 & 74 & 75 & 72 & 296 & 74 \\
\hline 7 & 007 & 60 & 58 & 63 & 59 & 240 & 60 \\
\hline 8 & 008 & 73 & 75 & 80 & 76 & 304 & 76 \\
\hline 9 & 009 & 71 & 73 & 82 & 72 & 300 & 75 \\
\hline 10 & 010 & 60 & 65 & 73 & 60 & 248 & 62 \\
\hline 11 & 011 & 71 & 72 & 78 & 72 & 292 & 73 \\
\hline 12 & 012 & 58 & 59 & 65 & 58 & 240 & 60 \\
\hline 13 & 013 & 71 & 72 & 77 & 72 & 292 & 73 \\
\hline 14 & 014 & 70 & 68 & 75 & 67 & 280 & 70 \\
\hline 15 & 015 & 68 & 70 & 78 & 72 & 288 & 72 \\
\hline 16 & 016 & 72 & 70 & 78 & 72 & 292 & 73 \\
\hline 17 & 017 & 61 & 62 & 70 & 63 & 256 & 64 \\
\hline 18 & 018 & 67 & 70 & 75 & 68 & 280 & 70 \\
\hline 19 & 019 & 60 & 60 & 64 & 60 & 256 & 64 \\
\hline 20 & 020 & 70 & 70 & 75 & 69 & 284 & 71 \\
\hline 21 & 021 & 70 & 68 & 75 & 67 & 280 & 70 \\
\hline 22 & 022 & 69 & 70 & 75 & 70 & 284 & 71 \\
\hline \multirow[t]{3}{*}{23} & 023 & 70 & 69 & 72 & 75 & 286 & 71 \\
\hline & \multicolumn{5}{|c|}{ Ketuntasan } & \multicolumn{2}{|r|}{$73,91 \%$} \\
\hline & \multicolumn{5}{|c|}{ Rerata Kelas } & & 69,5 \\
\hline
\end{tabular}

Pada siklus I siswa kelas I tidak ada yang absen, yakni sejumlah 23 orang. Berdasarkan tabel di atas, maka hasil evaluasi terhadap keterampilan membaca permulaan (cerita) siswa memperoleh hasil, satu orang mendapatkan skor 76, dua orang mendapat skor 75 , satu orang mendapat skor 74, tiga orang mendapat skor 73, satu orang mendapat skor 72, empat orang mendapat skor 71 ,

lima orang mendapat skor 70 , dua orang mendapat skor 64, satu orang mendapat skor 63 , satu orang mendapat skor 62, satu orang mendapat skor 60 . Skor tertinggi yang diperoleh siswa, yakni 76 ,dan rata-rata kelas yang dicapai pada tindakan siklus I adalah 69,5. Dengan demikian, dapat disimpulkan bahwa keterampilan membaca permulaan (cerita) siswa kelas I SD Negeri4 TakmungKlungkung pada siklus I tergolong cukup. Berdasarkan pengamatan dan penilaian terhadap kemampuan membaca siswa, pada umumnya mereka membaca cerita tentang benda-benda yang telah diamati berdasarkan kartu huruf sebagai 
media pembelajaran dilihat dari segi kelemahan dan kelebihan yang dimiliki benda tersebut. Siswa mengamati bendabenda yang tertulis dalam kartu. Mereka (siswa) secara nyata mengamati kata-kata yang tertulis dalam, kartu misalnya kata "meja". Pada kartu tertulis kata "meja", kemudian siswa mengamati dan menyebutkan kata tersebut. Setelah diamati, siswa masih kurang dalam pengucapan lafal, penyusunaan kata-kata yang kurang baik contohnya, volume suara kurang jelas dan menggunakan kata-kata yang tidak benar pengucapannya seperti karna, dapetin. Berdasarkan pengamatan yang telah dilakukan, pada saat siswa membaca kata tentang "meja" siswa mengungkapkan kata-kata seperti karna, dapetin. Dari segi intonasi, intonasi siswa saat membaca dengan media gambar dan kartu huruf sudah cukup bagus, namun masih ada beberapa siswa yang intonasinya kurang tepat saat membaca di depan kelas. Hal ini tampaknya perlu mendapat perhatian pada tindakan berikutnya.

Refleksi, Tindakan siklus I telah dilaksanakan dengan baik dan sesuai dengan perencanaan. Berdasarkan analisis terhadap hasil yang diperoleh pada tindakan I, ternyata masih ditemukan adanya kekurangan atau masalah, kekurangan atau masalah yang dimaksud adalah siswa kurang aktif bertanya. Guru perlu memberikan pembimbingan kepada siswa dan memotivasi siswa agar memperbaiki pengucapan vokal, konsonan, volume suara, dan kemampuan menyusun huruf-huruf untuk menjadi kata. Berdasarkan hasil refleksi pada tindakan I, perlu dilakukan perencanaan pembelajaran yang lebih baik pada tindakan II. Adapun perencanaan tindakan siklus II dapat dirinci sebagai berikut; 1) Guru memberikan apersepsi mengarah pada tujuan pembelajaran; 2) Guru mendeskripsikan sebuah benda dengan memperhatikan pengucapan

vokal, konsonan, volume suara dan susunan kata-kata; 3) Guru merangsang keaktifan siswa bertanya, memberikan pendapat atau berkomentar dengan memberikan pujian; 4) Guru menyuruh siswa mengemukakan ide secara lisan; 5) Lima menit sebelum pembelajaran berakhir, guru dan siswa menyimpulkan materi; 6) Guru menutup pembelajaran.

Pelaksanaan tindakan siklus II sesuai dengan rencana semula. Pada pelaksanaan tindakan II ini, peneliti tetap dibantu oleh Ibu Ida Ayu Pt Candra Wati selaku guru bahasa Indonesia, sekaligus sebagai wali kelas I. Berikut ini akan diuraikan hasil penelitian pada tindakan siklus II.

Hasil Observasi, Berdasarkan hasil observasi yang dilakukan dapat diungkapkan hal-hal seperti berkut ini: Guru masuk kelas pada jam pelajaran 1-2. Guru menyuruh siswa merapikan meja dan tempat duduk, karena masih terlihat belum rapi. Guru menyampaikan indikator pembelajaran. Pada pertemuan sebelumnya, siswa diberikan tugas oleh guru membaca sebuah cerita, terutama mengenai benda kesayangannya. Kemudian guru memberikan pertanyaan mengenai buku yang telah dibaca oleh siswa. Ada yang membaca buku mengenai "mobil", "boneka", " televisi". Tiga kata tersebut ditulis oleh guru di papan tulis. Utami, salah seorang siswa mengatakan, bahwa ia dibelikan majalah Bobo oleh bapaknya. Majalah yang dibaca oleh seorang siswa itu (Utami) mengenai televisi. Guru memilih salah satu kata yang telah ditulis di papan tulis tadi, yaitu kata televisi. Guru menceritakan kata tersebut dan siswa hanya bengong saja. Ada yang bertopang dagu, seolah mereka heran melihat guru menceritakan kata tersebut. Guru memberikan pertanyaan kepada siswa mengenai benda yang diceritakan tadi. Guru mencoba memancing respon siswa dengan pertanyaan pancingan seperti, kalian tidak boleh takut, guru tidak akan memakan siswa, guru memastikan ada siswa menjawab pertanyaan. Dengan kalimat pancingan seperti itu, ada tiga orang siswa yang mau mengangkat tangannya. Kemudian guru bertanya lagi kepada siswa mengenai pendapat mereka.

Dua siswa menjawab pertanyaan guru dengan benar. Guru memberikan pujian dengan kata "bagus". Berdasarkan jawaban siswa tersebut, guru menyimpulkan materi yang diajarkan.

Setelah dua puluh menit pelajaran berlangsung, suasana kelas seperti tidak 
nyaman, karena banyak siswa kelas lain berdiri di depan pintu, sehingga konsentrasi siswa mengikuti pelajaran menjadi terganggu. Guru menutup pintu kelas. Namun, masih ada siswa yang menoleh keluar dan tidak memperhatikan guru, kemudian guru menegurnya. Dengan teguran itu, siswa mulai berkonsentrasi lagi.

Guru menulis kata lafal di papan tulis. Kemudian guru menanyakan mengenai lafal kepada siswa. Semua diam dan menoleh kekanan dan kekiri. Setelah dua menit, akhrinya ada siswa yang mau menjawab. Itu pun guru harus berusaha keras agar siswa mau mengemukakan pendapat mereka. Guru memberikan contoh cara siswa bembaca (bercerita) pada tindakan pada siklus I. Semua siswa tertawa karena guru bercerita. Pada tindakan sebelumnya (tidakan I) masih ada siswa yang loyo dalam membaca, khususnya dalam hal pengucapan lafal (vokal, konsonan, volume suara) dan kata-kata yang digunakan. Setelah kegiatan tersebut, guru bertanya kepada siswa mengenai pemahaman mereka terhadap kegiatan yang telah dilaksanakan. Siswa menjawab serentak bahwa mereka tidak ada yang bertanya.

Seorang siswa mengangkat tangannya dan mengatakan belum ada pertanyaan, nanti setelah mereka mengerjakan tugas dan menemui kesulitan barulah mereka akan bertanya. Karena siswa tidak ada yang bertanya, guru membagikan potongan-potongan kartu yang berkaitan dengan lingkungan sekolah. Huruf-huruf pada tindakan I masih dipakai sebagian. Setelah guru membagikan potongan-potongan kartu itu, siswa mencari pasangannya. Guru menyuruh siswa mengamati benda-benda yang tertulis dalam kartu huruf dan membawa itu kedalam kelas. Sekitar sepuluh menit siswa kembali ke kelas. Ada siswa yang langsung menulis hurufhuruf yang akan dijadikan bahan bacaan (cerita). Guru memberikan kesempatan kepada siswa untuk memikirkan hurufhuruf yang telah dibagikan yang ada pada kartu.

Tindakan ini tidak cukup dilakukan sekali pertemuan, tetapi dilakukan dalam dua kali pertemuan. Pertemuan pertama, siswa tidak mampu mengemukakan ideide yang mereka miliki secara lisan. Dengan pujian, barulah mereka mau membaca (cerita) tanpa ditunjuk. Namun pada pertemuan berikutnya, tanpa ditunjuk mereka langsung mengangkat tangan untuk membaca (cerita). Kata-kata seperti wah, cantik, duhai kekasihku, pacarku, dan masih banyak kata-kata yang muncul dari siswa. Siswa yang lain mendengarkan cerita dengan suasana hening. Guru tersenyum mendengar siswa membaca (cerita).

Kemudian guru memberikan komentar dengan memberikan pujian. Siswa bersemangat dengan diberikan pujian. Siswa yang sudah mendapatkan giliran membaca (cerita) menunjuk teman dan menyuruh teman itu bertanya mengenai benda yang telah diceritakan. Setelah semua mendapat giliran menceritakan benda yang diamati berdasarkan permainan kartu huruf yang dijadikan media, guru memberikan komentar sekaligus memberikan kesimpulan dan menutup pelajaran. Hasil Evaluasi, Hasil evaluasi dalam siklus II menunjukkan adanya peningkatan dalam skor. Skor rata-rata pada siklus I yang hanya mencapai 69,5, pada siklus II meningkat menjadi 72,2 pada siklus II. Ketuntasan klasikal meningkat dari $73,91 \%$ pada siklus I menjadi $82,60 \%$ pada siklus II. Secara lebih jelas, hasil evaluasi dapat dilihat pada tabel berikut. 
Tabel 02: Hasil Evaluasi Membaca Siswa Kelas I SD Negeri 4 Takmung-Klungkung pada Silkus II

\begin{tabular}{|c|c|c|c|c|c|c|c|}
\hline \multirow{2}{*}{ No. } & \multirow[b]{2}{*}{ Kode Siswa } & \multicolumn{4}{|c|}{ Aspek yang Dinilai } & \multirow[b]{2}{*}{ Jumlah } & \multirow{2}{*}{ Rata-rata } \\
\hline & & 1 & 2 & 3 & 4 & & \\
\hline 1 & 001 & 70 & 72 & 76 & 70 & 288 & 72 \\
\hline 2 & 002 & 64 & 66 & 70 & 68 & 268 & 67 \\
\hline 3 & 003 & 68 & 70 & 72 & 70 & 280 & 70 \\
\hline 4 & 004 & 67 & 70 & 75 & 68 & 280 & 70 \\
\hline 5 & 005 & 75 & 76 & 78 & 75 & 304 & 76 \\
\hline 6 & 006 & 71 & 72 & 78 & 72 & 292 & 73 \\
\hline 7 & 007 & 67 & 67 & 71 & 67 & 272 & 68 \\
\hline 8 & 008 & 75 & 76 & 78 & 77 & 308 & 77 \\
\hline 9 & 009 & 78 & 80 & 82 & 80 & 320 & 80 \\
\hline 10 & 010 & 60 & 62 & 70 & 60 & 252 & 63 \\
\hline 11 & 011 & 71 & 73 & 78 & 71 & 292 & 73 \\
\hline 12 & 012 & 73 & 75 & 78 & 74 & 300 & 75 \\
\hline 13 & 013 & 73 & 73 & 76 & 74 & 296 & 74 \\
\hline 14 & 014 & 70 & 68 & 75 & 67 & 280 & 70 \\
\hline 15 & 015 & 72 & 73 & 79 & 72 & 296 & 74 \\
\hline 16 & 016 & 74 & 73 & 78 & 74 & 300 & 75 \\
\hline 17 & 017 & 70 & 72 & 76 & 70 & 288 & 72 \\
\hline 18 & 018 & 71 & 72 & 77 & 72 & 292 & 73 \\
\hline 19 & 019 & 68 & 67 & 73 & 68 & 276 & 69 \\
\hline 20 & 020 & 68 & 68 & 75 & 70 & 280 & 70 \\
\hline 21 & 021 & 70 & 68 & 75 & 67 & 280 & 70 \\
\hline 22 & 022 & 74 & 75 & 80 & 75 & 304 & 76 \\
\hline \multirow[t]{3}{*}{23} & 023 & 70 & 76 & 80 & 70 & 296 & 74 \\
\hline & \multicolumn{6}{|c|}{ Ketuntasan } & $82,60 \%$ \\
\hline & \multicolumn{6}{|c|}{ Rerata Kelas } & 72,21 \\
\hline
\end{tabular}

(Sumber: Adaptasi dari Arsjad dan Mukti, 1993:87)

Silkus II dilaksanakan pada pertemuan ke-3 dengan melaksanakan 1 kali penilaian dengan 4 aspek penilaian. Pada siklus II ini, ketuntasan belajar dicapai oleh 19 orang dari jumlah keseluruhan, yakni 23 siswa. Adapun urutan pemerolehan skor yaitu skor 80, diperoleh satu orang, skor 77 , diperoleh satu orang, skor 76 diperoleh dua orang, skor 75 diperoleh dua orang, skor 74 diperoleh tiga orang, skor 73 diperoleh tiga orang, skor 72 diperoleh dua orang, skor 70 diperoleh lima orang, skor 69 diperoleh satu orang, skor 68 diperoleh satu orang, skor 67 diperoleh satu orang, dan skor 63 diperoleh satu orang. Sekor tertinggi diperoleh satu orang dengan nilai 80 dan skor terendah dengan nilai 63 diperoleh satu orang.

Sebelum dilakukan pembahasan, berikut ini ditegaskan terlebih dahulu hasilhasil penelitian yang diperoleh. Ketiga hasil penelitian tersebut adalah : (1) penerapan permainan kartu huruf sebagai media pembelajaran dapat meningkatkan keterampilan membaca permulaan, (2) penerapan media gambar sebagai media pembelajaran dapat merangsang minat belajar siswa, dan (3) penerapan media gambar dan kartu huruf memberikan motivasi pada guru dalam proses pembelajaran sehingga mempengaruhi peningkatan hasil belajar siswa. Ketiga hasil penelitian tersebut dapat dipaparkan berikut ini. 
Media pembelajaran berupa permainan kartu huruf yang diterapkan guru dalam pembelajaran bahasa Indonesia, berpengaruh terhadap peningkatan keterampilan membaca permulaan yang dicapai siswa. Kartu huruf sebagai media pembelajaran dapat dirancang, dipersiapkan untuk maksud dan tujuan pembelajaran sehingga mampu mengaktifkan siswa dalam proses belajarmengajar. Sejalan dengan pendapat Rahadi (2003 : 17), yaitu kegiatan belajarmengajar dapat terlaksana dengan media yang dirancang sedemikan rupa. Dalam proses belajar-mengajar, media yang sederhana dan murah pun mampu meningkatkan hasil belajar siswa, khususnya dapat membantu siswa dalam mengungkapkan ide-ide yang dimilikinya.

Penerapan permainan kartu huruf sebagai media pembelajaran di kelas I SD Negeri 4 Takmung-Kungkung ternyata telah mampu meningkatkan keterampilan siswa untuk mengungkapkan ide-ide yang mereka miliki khususnya dalam bercerita. Arif S. Sadiman, dkk. (2006:79) menyatakan bahwa permainan dapat dipakai untuk membantu siswa atau warga belajar meningkatkan kemampuan komunikatifnya, memahami pendapat orang lain, memimpin diskusi, dan sebagainya. Hasil penelitian yang sama juga didapatkan oleh Kotha Artika (2004), dengan penerapan kartu huruf dan media gambar telah mampu meningkatkan keterampilan membaca siswa dengan kategori 65\%-79\% tergolong cukup baik pada siklus I dan kategori $80 \%-89 \%$ tergolong baik pada siklus II. Ini disebabkan oleh proses pembelajaran yang menyesuaikan dengan karakteristik siswa. Pada usia awal anak masuk SD, anak belum memahami secara jelas apa yang dipelajari tanpa bantuan benda konkret. Salah satu upaya yang dapat dilakukan adalah menggunakan media dalam pembelajaran. Pada pembelajaran membaca, khususnya membaca permulaan media yang cocok digunakan adalah media gambar dan kartu huruf. Kedua media ini mampu mengarahkan siswa untuk lebih memaknai pembelajaran yang telah dilakukannya. Begitu pula media ini mampu menarik perhatian siswa agar lebih fokus saat belajar karena diselingi dengan permainan yang menghibur siswa. Dengan demikian dari hasil penelitian tersebut, keterampilan membaca siswa akan berkembang apabila media yang digunakan sesuai dengan karakteristik siswa.

Keterampilan

membaca merupakan keterampilan langsung secara teoretis, produktif, dan ekspresif. Apabila itu dirangsang oleh seorang guru, bagi siswa tertentu malah menghambat kelancaran berbicaranya. Lain halnya apabila stimulus tersebut diberikan oleh teman sebayanya. Stimulus yang diberikan teman sebaya juga mampu mengembangkan kemampuan menyimak yang sifatnya langsung, apresiatif, dan reseptif. Tidak semua stimulus yang bersumber dari teman sebaya dapat menghilangkan rasa gugup atau respon negatif siswa. Untuk itulah diperlukan bantuan berupa alat (media). Berbicara dengan alat bantu diyakini akan menghasilkan tanggapan informasi yang lebih baik pada pihak penyimak (Tarigan,1990).

Selain media kartu huruf, media gambar juga memiliki peranan yang penting dalam peningkatan keterampilan membaca permulaan siswa SD Negeri 4 Takmung. Peranan tersebut, yakni dengan penerapan media gambar siswa menjadi berminat untuk belajar membaca. Siswa yang sebelumnya kurang berminat dalam belajar membaca menjadi tertarik dan tertantang untuk belajar membaca setelah guru menunjukkan gambar-gambar yang menarik pada siswa. Pada dasarnya setiap siswa memiliki minat yang sama terhadap pembelajaran, namun minat tersebut perlu dirangsang dan dikembangkan agar siswa tidak malas ketika proses pembelajaran berlangsung. Sesuatu yang mampu menarik minat siswa akan membantunya untuk belajar lebih banyak dan konsep yang dipelajarinya akan lebih melekat apabila pemahaman tersebut berasal dari diri siswa sendiri. Dengan demikian, penerapan media gambar dan kartu huruf cukup efektif diterapkan sebagai upaya untuk meningkatkan keterampilan membaca permulaan. Hal ini sesuai dengan data tentang peningkatan hasil belajar siswa pada siklus I dan siklus II, 
yakni skor rata-rata yang diperoleh siswa pada siklus I sebesar 69,5 meningkat menjadi 72,2 pada siklus II.

Peningkatan ini tidak dapat dilepaskan dari adanya faktor guru dan siswa sendiri. Guru sebagai pelaksana pengajaran telah termotivasi untuk menggunakan media pembelajaran. Biasanya guru hanya bergantung pada buku tanpa ada media khusus dan konkrit untuk pembelajaran. Akan tetapi, dalam penelitian ini, guru telah mengadakan perubahan dalam pembelajaran, yaitu dengan merancang dan menemukan langkah-langkah pembelajaran membaca permulaan (cerita) dengan menerapkan permainan kartu huruf dan media gambar. Adapun langkah langkah pembelajaran yang ditemukan dan diterapkan guru sebagai berikut : (1) memulai pembelajaran dengan apersepsi yang mengarah kepada materi pembelajaran,

(2) menyampaikan indikator pembelajaran, (3) membagikan potongan kartu huruf, mencari pasangan, dan mengobservasi lingkungan sekolah, (4) melakukan tanya jawab sehubungan dengan materi pembelajaran, (5) memberikan kesempatan kepada siswa untuk bertanya, berpendapat, memberikan masukan mengenai materi yang telah disajikan, (6) memberikan kesempatan kepada siswa memikirkan kata-kata yang disajikan bahan membaca permulaan (cerita), (7) memberikan bimbingan, (8) memberikan komentar mengenai penampilan siswa, dan (9) menyimpulkan materi serta menutup pembelajaran.

Adanya perubahan cara mengajar yang dilakukan guru setelah diterapkannya media gambar dan kartu huruf, secara langsung telah mempengaruhi situasi pembelajaran di kelas.Siswa menjadi antusias dalam mengikuti pelajaran, tetapi keterlibatan siswa masih sangat minim. Guru berusaha mengaktifkan siswa dengan kalimat pancingan seperti siswa tidak boleh takut. Hal ini, dapat dilihat dari masing masingmasing langkah yang telah diterapkan oleh guru dalam kegiatan pembelajaran. Pada langkah (1) dan (2), guru telah memberikan contoh berkaitan dengan pembelajaran, tetapi siswa bengong dan ada yang terseyum saja menyimak contoh yang diberikan guru. Pada langkah (3), siswa cukup antusias melaksanakan kegiatan yang disuruh guru. Guru membagikan potongan-potongan kartu huruf.

Setelah siswa mendapatkan potongan-potongan kartu huruf, siswa mencari pasangan kartu huruf tersebut sehingga terbentuk kata yang bermakna. Hanya beberapasiswa yang bersemangat, sehingga siswa-siswa tersebut lebih cepat menemukan pasangan kartu hurufyang dimilikinya. Sekitar tujuh menit barulah semua siswa mendapat pasangan kartu huruf yang dimilikinya. Pada langkah (4) dan (5), guru memotivasi siswa agar mau melakukan aktivitas, tetapi yang aktif bertanya dan menjawab pertanyaan dalam pembelajaran hanya beberapa siswa saja. Seolah-olah siswa yang lain tidak ada di dalam kelas. Pada langkah (6) ketika guru menyuruh siswa memikirkan kata-kata yang akan dijadikan bahan membaca individual, ada beberapa siswa yang bercakap-cakap dengan teman sebangkunya. Guru mendatangi siswa tersebut. Guru menanyakan kesulitan yang dihadapi siswa mengenai kartu kata yang telah dibagikan. Siswa menggelenggelengkan kepalanya. Pada langakah (7) guru sudah memberikan komentar, seperti pengucapan lafal siswa dalam membaca kurang jelas dan volume suara perlu diperkeras.

Berdasarkan pelaksanaan langkahlangkah tersebut, guru telah berupaya secara maksimal untuk mengaktifkan siswa dalam pembelajaran, agar pembelajaran dapat terfokus pada siswa. Tetapi pada kenyataanya, menciptakan suasana pembelajaran yang terfokus pada siswa memerlukan waktu dan proses yang cukup lama, karena guru hanya berfungsi sebagai fasilitator atau motivator dalam pembelajaran. Walaupun ada banyak kesulitan dan hambatan dalam pelaksanaan pembelajaran, siswa tetap memberikan respon positif terhadap penerapan permainan media gambar dan kartu huruf sebagai media pembelajaran. Penerapan kedua media tersebut memudahkan siswa menuangkan gagasan mereka secara lisan melalui kegiatan membaca permulaan (cerita). Selain itu, mereka juga dapat 
mengobservasi secara langsung benda atau gambar yang diberikan. Nama-nama benda yang tertulis dalam kartu huruf tersebut, merupakan hal-hal yang terkait dengan kehidupan sehari-hari siswa.

Apabila tidak dibantu dengan menggunakan media konkret, siswa merasa kesulitan dalam mengungkapkan ide secara lisan sehingga mereka sering bertanya mengenai bahan-bahan apa yang diceritakan. Untuk mengatasi hal tersebut, diberikan alternatif media rancangan, yaitu permainan kartu huruf dan media gambar. Mereka juga termotivasi dalam mengemukakan ide secara lisan dengan menggunakan media rancangan tersebut. Oleh karena itulah, penggunaan permainan kartu huruf dan media gambar sebagai media pembelajaran dijadikan salah satu alternatif dalam pembelajaran membaca permulaan (cerita). Kohta Artika (2004), menyatakan bahwa dengan penerapan media pembelajaran yang bervariasi anak semakin meningkat kemampuan membaca pada anak semakin cukup baik ke katagori baik.

Penambahan jumlah media dalam pembelajaran memperlihatkan pengaruh yang positif terhadap kemampuan membaca pada anak. Niti Suartiari (2007), dengan memberikan permainan kartu huruf sebagai media pembelajaran, ternyata siswa mengalami kemajuan atau adanya peningkatan skor dalam membaca. Semua ini dapat dilihat dari skor rata-rata yang diperoleh siswa dari 73 pada siklus I menjadi 80,26 pada siklus II. Dilihat dari perolehan skor, siswa juga memberikan respon yang positif terhadap pembelajaran karena diterapkannya permainan kartu huruf sebagai media pembelajaran dapat meningkatkan ketrampilan membaca siswa.

\section{Simpulan dan Saran}

Bedasarkan hasil penelitian dan pembahasan pada bab IV, penerapan media gambar dan kartu huruf pada siswa kelas I semester II SD Negeri 4 TakmungKlungkung pada tahun pelajaran 2010/2011 dapat meningkatkan keterampilan membaca permulaan yang dapat dijabarkan sebagai berikut: 1) Hasil evaluasi belajar pada siklus I dan II menunjukkan bahwa penerapan media gambar dan kartu huruf dapat meningkatkan keterampilan membaca permulaan. Hasil yang telah dicapai menunjukkan, bahwa hipotesis yang telah dirumuskan pada bab II di depan, yaitu penerapan media gambar dan kartu huruf untuk meningkatkan keterampilan membaca permulaan di kelas I SD Negeri 4 Takmung- Klungkung, memang benar dan telah terbukti melalui penelitian.

Pada siklus I ketuntasan belajar siswa hanya mencapai $73,91 \%$,hal ini menunjukan keterampilan membaca siswa masih tergolong cukup karena $27 \%$ dari jumlah siswa belum mencapai ketuntasan belajar dengan nilai yang ditentukan. Pada siklus II terjadi peningkatan ketuntasan belajar, yakni dari 23 siswa, 19 siswa atau $82,60 \%$ dari jumlah siswa telah mencapai ketuntasan belajar, sehingga target yang ditentukan tercapai; 2) Pembelajaran dengan menggunakan media gambar dan kartu huruf sebagai media pembelajaran disambut gembira oleh siswa. Mereka senang dengan cara pembelajaran seperti itu karena merasa terbantu dalam pembelajaran. Akan tetapi, masih ada beberapa siswa yang mengalami kesulitan merangkai kartu huruf dan takut maju (ke depan) untuk membaca. Hal ini kemudian ditindak lanjuti pada siklus berikutnya sehingga kesulitan siswa dapat diminimalisir; 3) Peningkatan hasil belajar siswa tidak terlepas dari motivasi guru untuk menciptakan inovasi dalam kegiatan pembelajaran dengan cara membuat rancangan dan melaksanakan secara utuh langkah-langkah pembelajaran yang telah dirancang atau dirumuskan.

Saran, Adapun saran yang dapat penulis sampaikan berdasarkan simpulan yang telah dibuat, yakni sebagai berikut; 1) Berdasarkan hasil belajar yang telah diperoleh siswa, peningkatan hasil belajar tersebut sudah cukup baik, namun masih perlu adanya tindak lanjut dan upaya dari para guru untuk melanjutkan penggunaan media yang tepat untuk siswa guna meningkatkan hasil belajar siswa; 2) Guru perlu menanamkan rasa percaya diri pada siswa saat akan tampil ke depan kelas atau menunjukkan hasil kerjanya, ini karena kurangnya rasa percaya diri pada siswa akan menghambat proses belajar 
siswa tersebut. Guru perlu memberikan pendekatan dan cara pembelajaran yang menarik dengan penggunaan media yang tepat untuk siswa sehingga siswa akan lebih berani mengekspresikan dirinya saat belajar siwa harus dibiasakan agar mampu mengatasi kesulitan-kesulitan belajar membaca yang dialami dengan dukungan para guru dan media pembelajaran, dalam hal ini media gambar dan kartu huruf; 3) Kegiatan pembelajaran merupakan kegiatan yang terjadi secara terstruktur, yang artinya setiap kegiatan perlu direncanakan secara matang. Guru perlu lebih mematangkan persiapan sebelum memulai pembelajaran misalnya dengan mempersiapkan rencana pelaksanaan pembelajaran, silabus mata pelajaran, dan media pembelajaran. Dengan persiapan yang matang dan upaya yang maksimal, maka pembelajaran akan berjalan lancar dan optimal.

\section{Daftar Pustaka}

Abdurrahman, Mulyono. 2000. Pendidikan Anak Berkesulitan Belajar. Jakarta: Rineka Cipta.

Arikunto, Suharsini. 1998. Prosedur Penelitian Suatu Pendekatan Praktek. Yogyakarta: Rineka Cipta.

Arini, Ni Wayan, dkk. 2006. Peningkatan Keterampilan Berbahasa Indonesia Berbasis Kompotensi. Singaraja. Tim Penyusun.(tidak diterbitkan).

Artika, Made Oktha.2003. Meningkatkan Kemampuan Membaca dengan Menggunakan Kartu Kata dan Media Gambar pada Anak Kelas II Sekolah Dasar Negeri Subuk, Kecamatan Busungbiu, Kabupaten Buleleng Tahun Ajaran 2003/2004.Skripsi (tidak diterbitkan).

Basir. 1998. Persiapan Membaca Menulis Permulaan. Klaten : PT. Intan Pariwara.

Bukian, Ardana. 2004. Penerapan Model Pembelajaran Kontekstual Untuk Meningkatkan Keterampilan Membaca Siswa Kelas IV Sekolah Dasar Negeri Pempatan, Menanga,
Karangasem.Skripsi

(tidak diterbitkan).

Departemen Pendidikan Nasional. 2004. Strategi Belajar Mengajar. Jakarta: Depdiknas.

Departemen Pendidkan Nasional. 2006. Pedoman Teknis Penyelenggaraan Taman Penitipan Anak. Jakarta: Departemen Pendidikan Nasional.

Depdiknas. (2007). Pedoman

Pengembangan Bidang Seni di Taman Kanak-kanak. Jakarta.

Depdiknas. (2007). Pedoman

Pengembangan Fisik/Motorik di

Taman Kanak-kanak. Jakarta.

Djamarah, Syaiful Bahri dan Aswan Zain. 2002. Strategi Belajar Mengajar. Jakarta: RinekaCipta.

Elisabeth B. Hurlock. (1999). Perkembangan Anak. Jakarta: Erlangga

Kurnia, Rita. 2009. Metodologi Pengembangan Bahasa Anak Usia Dini. Pekanbaru: Cendikia Insani. 2009. Metode Pengembangan matematika Anak Usia Dini. Pekanbaru: Cendikia Insani. 2010. Evaluasi Pembelajaran Anak Usia Dini. Pekanbaru: Cendikia Insani.

Momo. 1979. Pengguanaan metode SAS Dalam Pengajaran di Sekolah Dasar. Jakarta : Depdikbud.

Musthafa, Fahim. (2005). Agar Anak Anda Gemar Membaca. Bandung: Hikmah Kelompok Mizan.

Nasution. 1972. Diktaktik Pengajaran Bahasa di Sekolah Dasar . Jakarta : Depdikbud.

Oka. 1983. Mengatur membaca dan penerapannya. Surabaya : Usaha Nasional

Sadiman, Arief S. 1990. Media Pendidikan Pengertian, Pengembangan, dan Pemanfaatannya. Jakarta: Pustekkom Dikbud \& CV Rajawali.

Sadiman, Arief S. 2006. Media Pendidikan. Jakarta: Rajawali Pers. 
Soedjono. A. 1993. Metodik Kusus Bahasa Indonesia.Bandung : Bina Aksara.

Suarni. 1996. Perkembangan Anak Sejak Dini. Tesis Singaraja : SPKN.

Suartiari, Niti. 2007. Penerapan Permainan Kartu Kata Sebagai Media Pembelajaran Untuk Meningkatkan Keterampilan Berbicara Siswa Kelas V SD No.3 Canggu-Badung.Skripsi (tidak diterbitkan).

Suendra Nyoman. 1993. Strategi mengajar Membaca Permulan Murid-murid Kelas I Sekolah Dasar. Malang : tesis IKIP malang.

Sujana, Nana. Media Pendidikan .Bandung : Alumni Bandung.

Tabrani Rusyan. 1993. Pendidikan Dalam Proses Pembelajaran. Bandung: Sinar Baru

Tampubolon, D.P. 1987. Kemampuan Membaca: Teknik Membaca Efektif dan Efesien. Bandung: Penerbit Angkasa.

Tarigan, Djago dkk. 1990. Materi Pokok Pendidikan Bahasa Indonesia I. Jakarta : P2LPTK PT Dekdikbud. 